\title{
Az aortaív-anomáliák klinikai jelentősége a magzattól a felnőttkorig
}

\author{
Hartyánszky István dr. - Bogáts Gábor dr. \\ Szegedi Tudományegyetem, Általános Orvostudományi Kar, Szent-Györgyi Albert Klinikai Központ, \\ Belgyógyászati-Kardiológiai Központ, Szívsebészeti Osztály, Szeged
}

\begin{abstract}
Az intrauterin echokardiográfiás és MR-diagnosztika fejlődése napjainkban jelentős szerepet tulajdonít már az első trimeszter idejében kimutatható aortaív-fejlődési rendellenességeknek. Célunk volt részletezni a vascularis gyưrük megjelenési formáit, ezek különböző életkorokban jelentkező tüneteit, sebészi kezelését, hogy hozzájárulhassunk a helyes felvilágosításhoz, mely alapvető lehet a szülés helyének megválasztásában, így meghatározhassák a magzat sorsát, perinatalis ellátását. A situs inversustól eltekintve a jobb oldali aortaív jelenléte mindig felhívja a figyelmet vascularis gyưrü, társuló szívhibák, genetikai betegségek, kromoszómaanomáliák jelenlétére, tehát a magzat további vizsgálata szükséges. Kettős aortaív esetén jelentkezhetnek olyan súlyos tünetek, melyek a megszületés után, kora csecsemókorban sebészi beavatkozást igényelhetnek (szükséges lehet a szülés helyének megválasztása!). Az aberráns jobb arteria subclavia önállóan nem alkot érgyürüt, a ritkán társuló truncus caroticusszal csak későbbi életkorban okozhat sebészi beavatkozást igényló enyhe tüneteket.
\end{abstract}

Orv Hetil. 2021; 162(48): 1920-1923.

Kulcsszavak: jobb oldali aortaív, vascularis gyürú, aberráns jobb arteria subclavia

\section{Clinical significance of the aortic arch and its malformations from fetus to adulthood}

Nowadays, the development of intrauterine echocardiography and MR diagnostics plays a significant role in aortic arch malformations detected during the first trimester. Our aim was to detail the manifestations of vascular rings, their symptoms at different ages and their surgical treatment options in order to determine the fate of the fetus and its perinatal care. Apart from situs inversus, the presence of the right aortic arch always draws the attention to the possible presence of vascular rings, associated heart defects, genetic diseases, or chromosomal abnormalities, therefore further examinations of the fetus are necessary. In the case of a double aortic arch, severe symptoms may occur, which may require surgery after birth and in early infancy (it may be necessary to choose the place of birth!). The right aberrant subclavian artery does not form a ring and may cause mild symptoms requiring surgery at a later age with rarely associated truncus carotid.

Keywords: right aortic arch, vascular ring, aberrant right subclavian artery

Hartyánszky I, Bogáts G. [Clinical significance of the aortic arch and its malformations from fetus to adulthood]. Orv Hetil. 2021; 162(48): 1920-1923.

(Beérkezett: 2021. március 24.; elfogadva: 2021. május 13.)

\section{Rövidítések}

$\mathrm{CT}=$ (computed tomography) komputertomográfia; $\mathrm{MR}=$ mágneses rezonancia

Az aortaív és a nyaki nagyerek fejlődési rendellenességei a diagnosztikus technika fejlődésével kerültek/kerülnek látótérbe. A súlyos stridoros panaszok hátterét kutatva, a kétirányú nyeletést és a bronchoszkópos diagnosztikát az 1980-as években elterjedt aortográfiás vizsgálatok tudták megerősíteni. Az akkor elkezdett tudományos feldolgozások tisztázták, rendszerezték az aortaív szabályos és kóros fejlődésének lehetőségeit, a vascularis gyűrúk kialakulásait és megjelenési formáit [1]. Nem véletlen, hogy ekkor kezdődött el e betegségek gyakoribb felismerése, pontosabb diagnosztizálása és mütéti korri- 
gálása [2-5]. A későbbiekben megjelent CT- és MRvizsgálatokkal készített látványos anatómiai képek megkönnyítik ezen fejlődési variációk felismerését. Az 1980-as években tett megállapítások, hogy a jobb oldali aortaív ritkán fordul elő izoláltan, gyakran társul vascularis gyürüvel vagy kamrai septumdefectussal társuló veleszületett szívhibával, nem kapták meg a megfelelő érdeklődést $[3,4]$.

Napjainkban a magzati diagnosztika jelentős fejlődése, a kétdimenziós mellett a háromdimenziós echokardiográfia és a magzati $\mathrm{MR}$ megjelenése változást hozott. E vizsgálatok segítségével már az első trimeszterben ki lehet mutatni az aortaívnek és ágrendszereinek normális és kóros eredését, lefutását, és így keresni lehet ezek esetleges társulásait genetikai kórképekkel és más, veleszületett szívhibákkal. Ha ez sikerül, akkor a „viszonylag” könynyen felismerhető aortaív-fejlődési rendellenességek felhívhatják a figyelmet súlyosabb kóros anomáliák keresésére, megszabva a magzat sorsát, a terhesség kihordását, a szülés helyének megválasztását, perinatalis (sürgős szívsebészi beavatkozás szükségessége!) ellátását [7-10]. Ezért fontos annak pontos tisztázása, hogy a vascularis gyưrü mely formái milyen életkorban okoznak panaszokat, igényelnek mútéti beavatkozást, és mikor szükséges esetleg sürgős újszülöttkori mútét.

A kialakuló aortaív-anomáliák a 6 primitív aortaívpár fejlődési zavaraira vezethetők vissza. A ventralis és dorsalis aorta, valamint a 6 ívpárat alkotó különböző szegmentumok kóros nyitva maradása, illetve részleges vagy teljes felszívódása magyarázza a különböző megjelenési variációkat. Normálisan a jobb dorsalis aorta 7-17-es szegmentuma és az 1., 2., 3., 5. aortaív szívódik fel - így alakul ki a bal oldali aortaín és ágai: (jobb oldali) arteria (a.) anonyma, bal a. carotis communis, bal a. subclavia (1. ábra). Ha nem a jobb, hanem a bal oldali dorsalis aorta 7-17-es szegmentuma szívódik fel, akkor situs inversust, tükörképet kapunk: jobb oldali aortain, (bal oldali) a. anonyma, jobb a. carotis communis, jobb a. subclavia [1].

\section{A kettős aortaív komplett formája}

A dorsalis aorta 7-17-es szegmentuma egyik oldalon sem szívódik fel, kórosan perzisztál. A jobb oldali aortaív jobb oldalról, a bal oldali bal oldalról kerüli meg a tracheát és az oesophagust, majd egyesülve folytatódik az aorta descendensben (2. ábra). A. anonyma nincs, mindkét ívből az azonos oldali a. carotis communis és subclavia ered. Az esetek $80 \%$-ában a jobb oldali ív a domináns, 10-10\%-ban a bal oldali, illetve a két ív azonos nagyságú. Az aorta descendens haladhat a gerinc bal oldalán és a jobb oldalán is, a kórkép további variációját okozva. Mivel az érgyưrú már a magzati életben is nyomja a tracheát, és azon súlyos szúkületet, malaciát okozhat, a legsúlyosabb esetek ritkán már a megszületés után a súlyos stridoros panaszok miatt igényelhetnek sebészi beavatkozást. A tünetek jelentős része csecsemőkorban jelent-

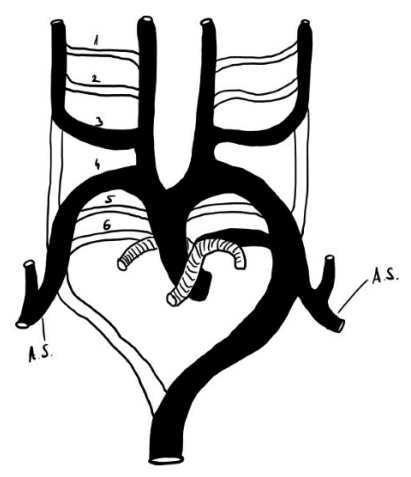

a)

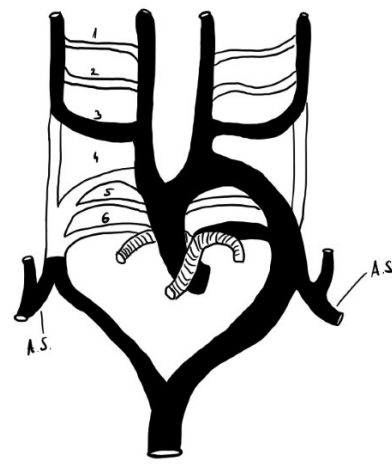

b)
1. ábra $\quad$ Az aortaívnek és ágainak (a), valamint az aberráns jobb arteria subclavia (b) kifejlődésének sémás rajza

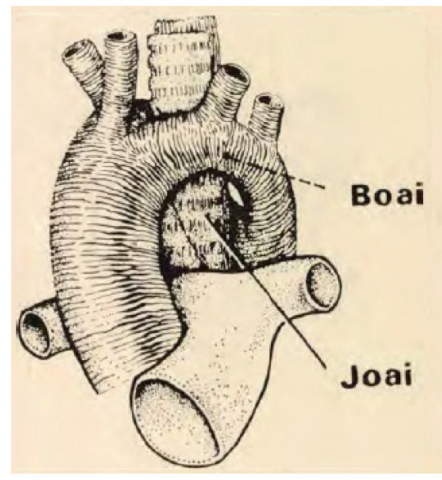

a)

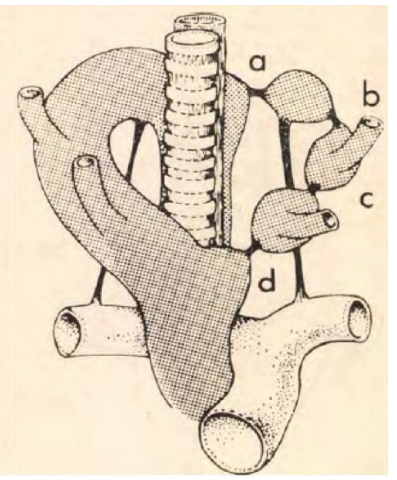

b) \begin{tabular}{l|l} 
2. ábra & $\begin{array}{l}\text { A kettôs aortaív (a) és a bal ív elzáródási variációi (b) Shuford [1] } \\
\text { után } \\
\text { Boai = bal oldali aortaív; Joai = jobb oldali aortaív }\end{array}$
\end{tabular}

kezik, amikor az 50-70\%-ban beszúkült trachea nyálkahártyája fertőzésre megduzzadva a légcső lumenét kritikusan beszúkíti. Ezért e típus felismerése, diagnosztizálása és sürgős sebészi megoldása általában kora csecsemókorban történik, ami a hypoplasiás ívnek az isthmus magasságában történő átmetszését jelenti, a ductus/ligamentum átmetszésével kiegészítve.

\section{A kettős aortaív „inkomplett” formája}

Amikor a kettős aortaív kialakul, a jobb oldali in mindig perzisztál, de a bal oldali ív különböző szegmentumai részlegesen felszívódnak, köteg formájában komplettálják a gyưrüt - ezek a következők lehetnek: a) a descendens és ductus arteriosus eredése, b) a ductus arteriosus és a bal a. subclavia eredése, c) a bal a. subclavia és a. carotis communis eredése, d) a bal a. carotis communis eredése és az ascendens között (2. ábra). A bal oldali ív distalis, a jobb oldali descendensbe szájadzó része diverticulumszerüen megmaradhat (Kommerell-diverticulum), ebból ered a ductus/ligamentum arteriosum. Mi- 
vel ez a gyưrü lazább, a tünetek is enyhébbek lehetnek, de tüneteket ezek is csecsemőkorban adnak. A mütéti megoldást az ívet alkotó köteg és a ductus/ligamentum átmetszése jelenti.

\section{Jobb oldali aortaív bal ductus/ligamentum arteriosummal}

A perzisztáló jobb oldali aortaív mellett a bal oldali aortaív fent felsorolt szakaszai teljesen felszívódnak (2. ábra). Az a) típus kivételével az összes típus úgy alkot gyưrüt, hogy: jobb oldali aortaív - descendensből telődő bal aortaívszakasz (mely így hátulról kerüli meg a tracheát és az oesophagust), amelyet a bal ductus/ligamentum fixál a bal a. pulmonalishoz. Megvan az érgyưrü, de láthatóan sokkal lazább, mint a kettős aortaív esetén. Ezért a panaszok, tünetek is enyhébbek, általában kisdedkorban kerülnek látótérbe. A mútéti megoldást a ductus/ ligamentum átmetszése jelenti.

\section{Aberráns jobb a. subclavia, a. lusoria}

A jobb dorsalis aorta 7-17-es szegmentuma perzisztál, de a jobb 4. aortaív felszívódik. A bal oldali aortaív normálisan fejlődik, az ívból a jobb a. carotis communis, a bal a. carotis communis és a bal a. subclavia normálisan ered, de a jobb a. subclavia a bal aorta descendensból (negyedik ágként) ered, majd az oesophagus mögött (ritkán előtte) húzódik át a jobb kar irányába (1. és 3. ábra). Az atípusosan lefutó ér gyürüt nem képez. Hátulról nyomja az oesophagust, de az van annyira rugalmas, hogy ki tud térni előle. Ritkán társulhat olyan fejlődési variációval, hogy a két a. carotis communis közös törzszsel ered (truncus caroticus), és ez a villa elölról megtámasztja a tracheát, nem engedi elöremozdulva kitérni a tracheát és a nyelőcsövet, így azokon enyhe szúkü̈letek keletkeznek. A panaszok általában darabos ételek nyelé- sekor kezdődnek, és a tünetek olyan enyhék, hogy beavatkozást csak gyermek-, kora felnőttkorban igényelhetnek. Sebészi megoldás: jobb oldalról felkeresve az a. subclavia eredését, az eret levágva az aorta descendensről, majd visszahúzva a jobb mellkasba, direkt vagy műér közbeiktatásával beültetendő az aorta ascendensbe.

\section{Pulmonalis hurok, sling}

A 6. primitív aortaív fejlődési rendellenessége [6]. A bal a. pulmonalis a jobb a. pulmonalisból eredve a jobb fóbronchus eredését megkerülve a trachea és az oesophagus között halad a bal hilusba (3. ábra). A szúkület distalisan, a trachea-bronchus határon van, a benyomat az oesophagus elülső oldalán keletkezhet. A tünetek súlyosak, már születés után is jelentkezhetnek. A sürgős sebészi megoldást a bal a. pulmonalis jobb ágról történő lemetszése, bal mellkasfélbe húzása, majd az a. pulmonalis törzsbe szájaztatása jelenti. Kritikus esetben olyan súlyos tracheamalaciát okozhat, hogy tracheaplasztikai megoldások válhatnak szükségessé.

\section{Megbeszélés}

Az aortaív fejlődési rendellenességeit vizsgálva megállapíthatjuk, hogy csak azok a variációk okoznak olyan súlyos, újszülött-, csecsemókorban sebészi beavatkozást igénylő tracheaszúkületeket, melyeknél a jobb oldali aortaív mindig perzisztál (intrauterin „U shaped” echokardiográfiás jel [7]). A jobb oldali aortaív gyakran társul kamrai septumdefectussal társuló veleszületett szívhibával (kamrai septumdefectus, Fallot-tetralógia, truncus arteriosus communis, kettős kiáramlású jobb kamra stb.) is $[3,4,7,8]$. Ezen szívfejlődési rendellenességek társulását genetikai elváltozásokkal már régóta sikeresen kutatják. D’Antonio [9] (16 centrum anyagából) 312 magzatot vizsgálva a jobb oldali aortaívek 25\%-ában igazolt
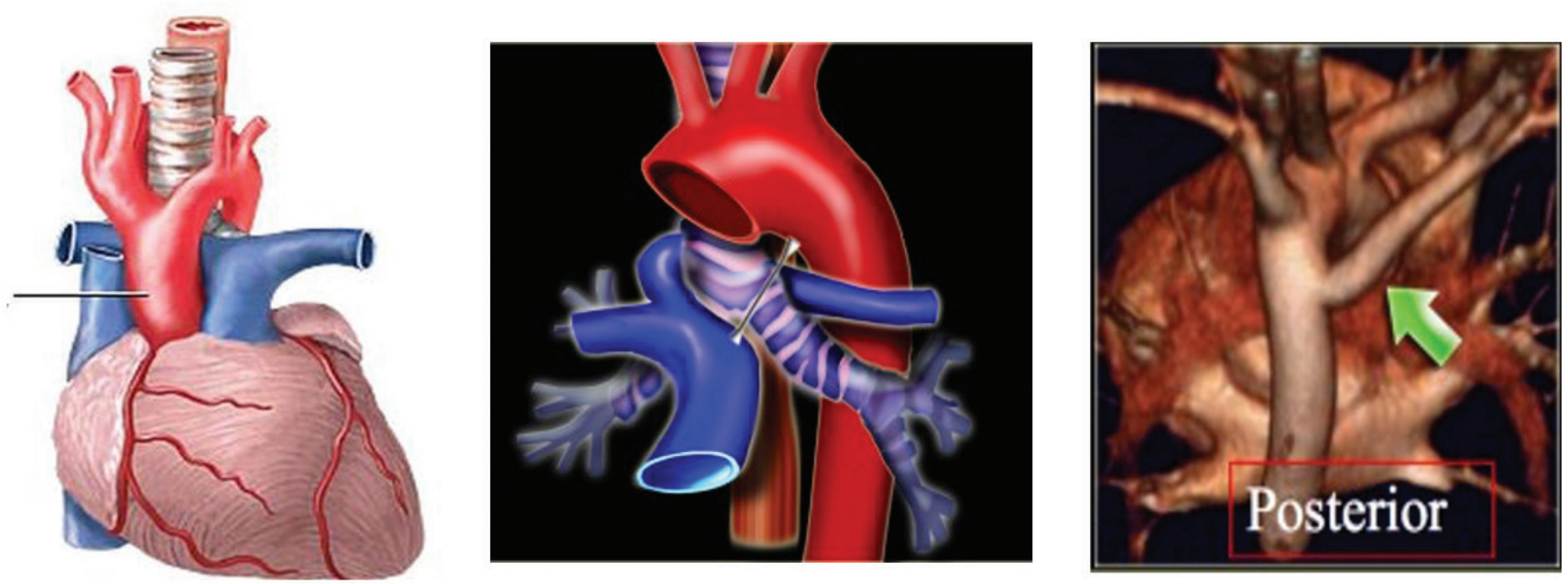

3. ábra Kettős aortaív, pulmonalis sling, aberráns jobb arteria subclavia MR-képe
$\mathrm{MR}=$ mágneses rezonancia 
vascularis gyürüt, 9 (6-12,5) \%-ban kromoszómaanomáliát, 6,1 (3,6-9,3) \%-ban 22q11,2-deletiót, 14,6 (10,319) \%-ban extracardialis, $5,1(2,4-8,6) \%$-ban intracardialis fejlődési rendellenességet. Luo [10] (22 centrum közleményeit vizsgálva) 610 fetusban izolált jobb oldali aortaív esetében kromoszómaanomáliát 7,5 (4,7-10,8) \%-ban, 22ql1,2-deletiót 4,3 (2,6-6,4) \%-ban mutatott ki.

Az aberráns jobb a. subclavia kóros lefutásának direkt ábrázolása sikeres már a magzati korai echokardiográfiával is [9]. A 111 operált vascularis gyürüs esetünk közül csak 8 volt aberráns jobb a. subclavia, és ezeket is csak gyermekkorban kellett operálni [5].

Felnőttkorban a Kommerell-diverticulum okozhat problémát. Barr 74 centrumból 99 beteg (átlagéletkor 61 év) adatait dolgozta fel [11]. A mútétileg, hibrid, illetve izolált endovascularis intervencióval megoldott, jobb oldali aortaívhez társuló aneurysmák és dissectiók 50\%-a a Kommerell-diverticulumból eredt [11].

\section{Következtetés}

1) Az aberráns jobb a. subclavia felismerése nagyon ritkán okozhat tracheakompressziós tüneteket, ha mégis, az általában gyermekkorban jelentkezik. A szülést ezért nem szükséges speciális centrumban végezni. 2) A jobb oldali aortaív felismerése jelentős segítséget jelent, és további vizsgálatot igényel! Tisztázandó vascularis gyűrü vagy társuló vitium jelenléte! (Ekkor már javasolt speciális centrumokban a szülés!) Keresendők lehetséges kromoszómabetegségek, illetve fontos a genetikai elváltozások igazolása, kizárása. 3. Kommerell-diverticulum esetén javasolt a felnőttkori utánkövetés is.

Anyagi támogatás: A közlemény megírása anyagi támogatásban nem részesült.

Szerzői munkamegosztás: A szerzők azonos mértékben vettek részt az irodalomgyújtésben és a kézirat megírásá- ban. A cikk végleges változatát mindkét szerző elolvasta és jóváhagyta.

Érdekeltségek: A szerzőknek nincsenek érdekeltségeik.

\section{Irodalom}

[1] Shuford WH, Sybers RG. The aortic arch and its malformations. Charles C. Thomas, Springfield, IL, 1974.

[2] Székely E, Farkas É. Trachea stenosis in infants and children. [Légcsőszúkület a csecsemő- és gyermekkorban.] Medicina Könyvkiadó, Budapest, 1977. [Hungarian]

[3] Hartyánszky I, Lozsádi K. Prognostic significance of right aortic arch. [A jobb oldali aortaív prognosztikai jelentősége.] Orv Hetil. 1978; 119: 1345-1348. [Hungarian]

[4] Hartyánszky I. Malformations of the primitive aortic arch in the light of congenital heart defects. [A primitív aortaívek fejlődési rendellenességei a congenitalis vitiumok tükrében.] Kandidátusi értekezés. Budapest, 1984. [Hungarian]

[5] Hartyánszky IL, Lozsádi K, Marcsek P, et al. Congenital vascular rings: surgical management of 111 cases. Eur J Cardiothorac Surg. 1989; 3: 250-254.

[6] Hartyánszky I, Lozsádi K, Várkonyi P, et al. Succesful surgical management of pumonary sling in infants. [Csecsemókorban sikeresen operált arteria pulmonalis hurok („pulmonary sling”).] Orv Hetil. 1982; 123: 1491-1493. [Hungarian]

[7] Campanale CM, Pasquini L, Santangelo TP, et al. Prenatal echocardiographic assessment of right aortic arch. Utrasound Obstet Gynecol. 2019; 54: 96-102.

[8] Cavoretto PI, Sotiriadis A, Girardelli S, et al. Postnatal outcome and associated anomalies of prenatally diagnosed right aortic arch with concomitant right ductal arch: a systematic review and meta-analysis. Diagnostics (Basel) 2020; 10: 831-835.

[9] D'Antonio F, Khalil A, Zidere V, et al. Fetuses with right aortic arch: a multicenter cohort study and meta-analysis. Ultrasound Obstet Gynecol. 2016; 47: 423-432.

[10] Luo O, Chen J, Zhang Y, et al. Incidence of chromosomal anomalies in fetuses with isolated right aortic arch: a meta-analysis. Prenat Diagn. 2020; 40: 294-300.

[11] Barr JG, Sepehripour AH, Jarral OA, et al. A review of the surgical management of right-sided aortic arch aneurysms. Inter Cardiovasc Thorac Surg. 2016; 23: 156-162.

(Hartyánszky István dr., Szeged, Semmelweis u. 8., 6725 e-mail: hartyanszky@hotmail.com)

A cikk a Creative Commons Attribution 4.0 International License (https://creativecommons.org/licenses/by/4.0/) feltételei szerint publikált Open Access közlemény, melynek szellemében a cikk bármilyen médiumban szabadon felhasználható, megosztható és újraközölhető, feltéve, hogy az eredeti szerző és a közlés helye, illetve a CC License linkje és az esetlegesen végrehajtott módosítások feltüntetésre kerülnek. (SID_1) 